\title{
INTERNATIONAL CO-ORDINATION OF DOCUMENTATION
}

$\mathrm{T}$ HE growing realization on every hand of the importance of documentation to undertakings of every kind continues to be reflected in the attendance, papers and discussions at the International Conferences of the International Federation for Documentation. Founded as the result of an International Conference on Bibliography at Brussels in 1895, the Federation has become the recognized international organization for the discussion and co-ordination of methods and means for making available on demand the recorded facts relating to any and every subject of special study.

Although the Conference held at Zurich during August 10-14 last was one of the smaller so-called conferences of experts, which are held in alternate years between the full conferences of the Federation, some hundred and seventy members attended from seventeen different countries and thirty-nine papers were communicated, larger numbers than at many full conferences of the Federation in its earlier years. In expressing the welcomo of the Swiss Government, Vice-Chancellor Dr. Leimgruber referred to the special importance of administrative documentation as a means of rationalization. Dr. Alingh Prius, president of the International Federation for Documentation, in reply appreciated the suitability of Switzerland, with its four languages, as an examplo of collaboration, and Zurich, as an industrial town, as meeting places for the Conference.

Four subjects were selected for special study at this Conference, and administrative documentation was one of them. In a paper entitled "La documentation administrative en Belgique", M. Daniel Warnotte gave a detailed account of the state of official documentation services in Belgium. He was followed by M. A. B. Boutillier du Retail of Paris, who referred specially to the French decree of 1938 creating a national centre of documentation at the Bibliothèque nationale for co-ordinating the whole of French administrative documentation. In his paper, "Notice sur l'unification des methods de classement dans les administrations publiques Belges," M. O. Molle of Brussels stressed the importance of the general adoption of a standard system of classification.

A typical paper was that by MM. E. Mathys, E. Rickli, C. Frachebourg and R. Calame of Berne, entitled "La documentation dans les Administrations Suisses des Chemins de Fer Federaux, des Postes, Telegraphes, Telephones et des Douanes," which gave a striking account of the advantages of co-ordinating the work of a number of administrative libraries. Documentation proceeds from the need of an organization to put in order the processes of collecting, abstracting, preserving and supplying books, articles, data, reports, public documents and archives. It has taken a long time to realize that, when such documents are properly collected, abstracted and made available, they are capable of affording invaluable assistance in administration. The existence of the gap between the making of a record in any sphere of work and the placing of that record in the hands of the individual who may need it, is proved by the number of individuals who set themselves to make notes of information that may be useful to themselves. There is as great a step between this and the creation of a special organization for the purpose, as there was for our ancestors, when they decided to give up baking their own bread and to let the baker do it for all. For good or for evil, the need has brought the means, and documentalists, like the bakers, have come.

The medium for distributing the records of progress is the periodical press, but it speaks in so irregular and incoherent a manner that it is impossible, without documentation, to obtain a clear and concise view of any particular branch of knowledge. Documenta. tion is the remedy for the disorder that reigns in the production of documents. It enables a small country like Switzerland to avail itself of advances in knowledge and experimental results from all parts of the world.

In Switzerland, besides the National Library, there are some forty-nine libraries belonging to the Federal administration. The highly favourable results of co-ordinating the work of four of the larger of these libraries, namely, these of the Swiss Railways Department, the Post Office, the Telegraphs and Telephones Department and the Customs Department, has led to the serious consideration of a scheme for the co-ordination of all the administrative libraries in the country. For these four libraries, the acquisition, care and manipulation of books and periodicals is centralized in one library. Thus all the material of documentation, within the scope of the administrations concerned, is collected and dealt with in one place according to the best principals of librarianship and documentation. Each official knows where to go without delay for his material and information. Purchases are made systematically, without duplica. tion. There is economy of cost, staff, furniture, apparatus and material. A community of work between tho libraries is recognized, about which there is constant consultation, mutual advice and help. Each library retains its own special character and borrows books freely, as required, from the associated libraries. Periodicals pass from one library to another, or to local branches, sometimes at the rate of thirty an hour.

Since officials usually require documents relating to a particular topic rather than by a given author, a subject catalogue is needed, which must be very minutely subdivided. The Universal Decimal Classification has been adopted by all four libraries as being the most appropriate, thus becoming the basis of mutual co-operation. There are also author and various special catalogues.

In recent years the Swiss Government has realized the inefficiency and costliness of making a documentation of each subject as it arises, and a central documentation service has been organized for these Departments. Periodicals necessarily form the basis of this service. As these come in, data and other useful information are abstracted from them and entered on cards, which also are classified by the Decimal Classification. The cards are retained by the individual libraries, the Post Office having 
10,000 , the Telegraphs and Telephones centre 80,000 and the Railway Department 200,000. Mutual interchange is facilitated by the utilization of standard methods. The good results obtained could not have been achieved otherwise than by such a rationalization and are such that the same principles are likely to be extended to all the Swiss administrative libraries.

The Section devoted to the Division of Work between Iibraries and Documentalists attracted some very interesting papers. Mr. A. B. Berthold gave a survey of work on Union Catalogues in the United States in a paper entitled "Union Catalogues and Documentation". There are now forty-six such catalogues in various stages of completion in the United States. One is national in scope, with approximately 10,000,000 cards; 22 catalogues relate to library holdings in various regions; and 23 are devoted to works in large subject groups. The Federal Government's policy of providing free labour has been the chief factor in their growth, and microphotography has become the unchallenged basis for all such work. Besides indicating the location of books, union catalogues are useful in tending to standardize cataloguing procedure. But, as all such catalogues are arranged under authors, they are unable to provide any answers to inquiries for books on particular topics.

An able paper, "Aufgaben der Bibliotheken in Rahmen der Dokumentation", was contributed by Herr C. Walther of Aix-la-Chapelle. The library problem is to collect systematically the literature within its scope as completely as possible and to make it as fully available as possible to its users. For purposes of documentation, a complete collection of the world's output of useful literature, especially periodicals, is most important. The best aid to users that a library can provide is a complete catalogue of its holdings, with exact information of every part received. A detailed subject catalogue is also necessary. For the utilization of the material in the library, bibliographies and abstracting journals must be added. Since many librarians are born bibliographers, libraries can also serve their users by preparing bibliographies on special subjects within their scope.

In a paper entitled "Bibliotheken und Dokumentation", M. S. Dahl of Copenhagen stressed the need of the investigator for efficient documentation, and showed the difficulty of drawing a sharp line between the work of the librarian and the documentalist. In a similar strain, M. Henri Lemaitre of Paris referred in his paper on ' $\mathrm{L} 3$ documentation et les biblio. thèues", to the address to the International Committee of Libraries at Brussels last year by M. Marcel Godet, president of the International Federation of Associations of Librarians, who had pointed out the close relationship between the work of librarians and documentalists. Librarians are concerned more with intellectual culture, while documentalists are in. terested moro particularly in utilitarian considera. tions. Theoretically, documentation includes all, and librarianship is only a part; actually, documentation is a young movement, while librarianship is already full grown and can contribute much to the assistance of documentation.

Mr. Lancaster Jones, London, discussed the part libraries can play in the task of technical docu. mentation, showing how an elaborate organization is needed to discover even the existence of a considerable portion of the world's technical literature. By making its collections as complete as possible within its scope and issuing periodical catalogues, classified by subject, of its accessions, a library can perform an invaluable service to documentation. T'o this can be added a contribution towards a co-operative scheme for the complete subject-indexing of articles in the periodical literature.

The discussion in this Section led to the conclusion that, while the work of librarians is more passive and that of documentalists more active, no sharp line can be drawn between them, and the solution can be found only through the most complete collabora. tion.

Space does not permit mention of the papers of equal value that were contributed to the other two sections of the Conference, dealing, respectively, with Documentation in Industry and Photographic Reproduction Methods for Documentation Purposes. The whole are published in a volume and supplement entitled "Rapports: Fédération international dē Documentation, XVième Conférence, Zurich" (10 Swiss francs) and obtainable from the International Federation at Willem Witzenplein 6, The Hague, Netherlands. These should certainly be studied by all librarians and documentalists as well as by all those who are interested in the accessibility of information.

Finally, it must be mentioned that not the least factors in the success of the Conferenco were the delightful hospitality and kindness shown by its organizers.

\section{RHYTHMIC PROCESSES IN BIOLOGY}

\section{$\mathrm{T}$} HE second conference of the Internationalen Gesellschaft für Biologische Rhythmusforschung was held in the "Stads.-en Academische Ziekenhuis" in Utrecht (Holland) on August 25-26. In spite of the international situation the meeting was very successful, and papers were read by members from Holland, Germany, Sweden, Russia and Britain. The German language was used for the most part, but communications were also made in English and French.

The conference was opened by Dr. E. Forsgren, of Stockholm, the president of the Society. On the first day the papers covered a wide range of subjects.
Prof. F. Linke (Frankfort) dealt with the different rhythmic processes measured by the meteorologist and which may bo important to the biologist. Prof. R. Stoppel (Hamburg) described her work on leafmovements in plants in relation to time and other factors. F. H. Stieltjes (The Hague) discussed some interesting examples of rhythmic activity. Prof. van der Pol (Eindhoven) considered the mathematical aspects of certain phenomena, and showed by means of a most ingenious electrical model how it is possible to produce artificially the electrical changes associated with normal and abnormal heart beat. K. Mellanby (Sheffield) described the periodic netivity of two 